\title{
IMPLEMENTASI KEBIJAKAN PENANGANAN GELANDANGAN, PENGEMIS, TUNA SUSILA DAN ANAK JALANAN DI KOTA PALANGKA RAYA
}

\author{
Imanuel Jaya
}

\begin{abstract}
The problems of social welfare that are developing today show that there are citizens who have not fulfilled their basic needs properly because they have not received social services from the state. The existence of homeless people, beggars, prostitutes and street children is a joint task that must be immediately addressed by the Central Government and the Regional Government. In particular, the City Government of Palangka Raya has issued a policy contained in Regional Regulation No. 09 of 2012 concerning Handling of Bums, Beggars, Prostitutes and Street Children. Where this policy aims to provide understanding and skills for actors to be able to live normally in society. The theory used is George Edward III about policy implementation which consists of four indicators, namely, Communication, Resources, Disposition and Structure of the Bureaucracy. This study uses a descriptive research method with a qualitative approach that is obtained based on the researchers' reasoning ability in connecting facts, data, and information obtained during the research. The study was conducted in the City of Palangka Raya, the Office of Social Services of the City of Palangka Raya. Data collection methods used in the form of observation, interviews, and documents. Analysis of the data used is data reduction, data presentation and conclusion drawing. Based on the results of the study, related to the Implementation of the Homeless Handling Policy of Beggars and Street Children in Palangka Raya City, the results have been implemented for 6 years but have not had a significant impact. Lack of communication between related parties, inadequate human resources, Disposition (attitude) Implementing policies that have not been decisive become the main factor in the lack of maximum handling. As a supporting and inhibiting factor (Internal), so far the Social Service has received a budget from the Government in carrying out shortterm handling in the form of enforcement, rehabilitation (social and mental) and repatriation to the place of origin. As a limiting factor, in the long run the local government still does not have a social rehabilitation institution to provide work skills and social guidance. While from (External) which is a supporting and inhibiting factor is the culture of the community to be together care and not neglect, Political Wiill, and Regulation for the benefit of the community.
\end{abstract}

Keywords: Implementation, Homeless, Beggars, Prostitutes, Street Children 


\section{PENDAHULUAN}

Permasalahan mengenai kesejahteraan sosial memang pekerjaan rumah yang tak kunjung terselesaikan bagi Pemerintahan periode kapan pun baik di dunia maupun di Indonesia. Sebagai negara yang dikategorikan sebagai negara berkembang, Indonesia memiliki masyarakat dengan permasalahan kesejahteraan sosial yang cukup tinggi. Masalah kesejahteraan sering kali menjadi fokus utama pemerintah dalam pembangunan dengan membuat berbagai program untuk masyarakat. Menyelesaikan permasalahan sosial memang sangat kompleks, dibutuhkan kerjasama yang serius antara Pemerintah Pusat dan Pemerintah Daerah, baik Provinsi maupun Kabupaten/Kota. Bagi Pemerintah mewujudkan kesejahteraan sosial merupakan suatu realisasi dari tujuan bangsa yang tertera dalam UUD Negara Republik Indonesia Tahun 1945 yang mengamanatkan Negara untuk melindungi segenap bangsa Indonesia dan seluruh tumpah darah Indonesia, memajukan kesejahteraan umum, mencerdaskan kehidupan bangsa dan ikut melaksanakan ketertiban dunia berdasarkan kemerdekaan, perdamaian abadi dan keadilan sosial. Pembangunan kesejahteraan sosial, negara menyelenggarakan pelayanan dan pengembangan kesejahteraan sosial secara terarah dan berkelanjutan.

Beberapa contoh permasalahan sosial yang hingga kini masih menjadi pekerjaan

yang tak kunjung terselesaikan baik oleh pemerintah pusat dan pemerintah daerah adalah adanya gelandangan, pengemis, tuna susila dan anak jalanan. Sebagai suatu kota dengan pertumbuhan penduduk yang masih belum terlalu tinggi kota Palangka Raya menjadi salah satu sasaran bagi para pelaku gelandangan, pengemis, tuna susila dan anak jalanan untuk datang dan mencari penghasilan disini. Namun nyatanya keberadaan mereka justru berdampak kurang bagus bagi pemandangan Kota dan memiliki dampak negatif bagi kehidupan sosial masyarakat. Untuk mengatasi itu semua Pemerintah Kota Palangka Raya mengeluarkan kebijakan untuk menanganinya yaitu melalui Peratura Daerah Nomor 09 Tahun 2012 Tentang Penanganan
Gelandangan, Pengemis, Tuna Susila dan Anak Jalanan di Kota Palangka Raya. Setelah pembuatan kebijakan, proses terpenting ialah bagaimana mengimplementasikan kebijakan tersebut. Proses ini akan menjadi parameter apakah kebijakan tersebut berhasil atau tidak. Untuk itulah peran dari implementator sangat mempengaruhi output dan outcome dari sebuah penerapan kebijakan.

\section{TINJAUAN PUSTAKA}

\section{Implementasi}

Secara umum istilah implementasi dalam Kamus Besar Bahasa Indonesia memiliki arti pelaksanaan atau penerapan. Menurut Lane, implementasi sebagai konsep dapat dibagi ke dalam dua bagian. Pertama, implementation $=$ (Intention, Output, Outcome). Sesuai definisi tersebut, implementasi merupakan fungsi yang terdiri dari maksud dan tujuan, hasil sebagai produk dan hasil dari akibat. Kedua, implementasi merupakan persamaan fungsi dari implementation $=$ (Policy, Formator, Implementor, Initiator, Time). Penekanan utama kedua fungsi ini adalah kepada kebijakan itu sendiri, kemudian hasil yang dicapai dan dilaksanakan oleh implementor dalam kurun waktu tertentu (Sabatier \& Mazmanian: 1983).

\section{Kebijakan}

Menurut (Iskandar, 2012, dalam Abdullah Ramadhan), Kebijakan dapat didefinisikan sebagai serangkaian rencana program, aktivitas, aksi, keputusan, sikap, untuk bertindak maupun tidak bertindak yang dilakukan oleh para pihak (aktoraktor), sebagai tahapan untuk penyelesaian masalah yang dihadapi. Penetapan kebijakan merupakan suatu faktor penting bagi organisasi untuk mencapai tujuannya. Kebijakan tentu mempunyai hambatanhambatan tetapi harus mencari peluangpeluang untuk mewujudkan tujuan dan sasaran yang diinginkan. Hal tersebut berarti kebijakan tidak boleh bertentangan dengan nilai-nilai dan praktikpraktik sosial yang ada dalam masyarakat. 


\section{Implemenasi Kebijakan}

Implementasi kebijakan merupakan tahapan pelaksanaan keputusan diantara pembentukan sebuah kebijakan, seperti hanya pasal-pasal sebuah undang-undang legislatif, keluarnya sebuah peraturan eksekutif, dan keluarnya keputusan pengadilan, atau keluarnya standar peraturan dan konsekuensi dari kebijakan bagi masyarakat yang mempengaruhi beberapa aspek kehidupannya. implementasi kebijakan diperlukan karena adanya masalah kebijakan yang perlu diatasi dan dipecahkan). Implementasi kebijakan diperlukan karena adanya masalah kebijakan yang perlu diatasi dan dipecahkan. Edwards III memperkenalkan pendekatan masalah implementasi dengan mempertanyakan faktor-faktor apa yang mendukung dan menghambat keberhasilan implementasi kebijakan. Berdasarkan pertanyaan retoris tersebut dirumuskan empat faktor sebagai sumber masalah sekaligus prakondisi bagi keberhasilan proses implementasi, yakni komunikasi, sumber daya, sikap birokrasi atau pelaksana, dan struktur organisasi termasuk tata aliran kerja birokrasi. Empat faktor tersebut merupakan kriteria yang perlu ada dalam implementasi suatu kebijakan perlu ada dalam implementasi suatu kebijakan.

\section{METODE PENELITIAN}

Jenis penelitian ini adalah penelitian kualitatif dengan menggunakan pendekatan deskriptif yang tujuannya untuk menguraikan, menerangkan dan menjelaskan secara mendalam tentang keadaan yan terjadi di lapangan tanpa ada rekayasa. Sebagaimana yang di maksud menurut Sugiyono (2013:291) masalah dalam penelitian kualitatif bersifat sementara, Relatif dan akan berkembang atau berganti setelah peneliti berada di lapangan. Sehingga penelitian mengenai Implementsi kebijakan gelandangan, pengemis, tuna susila dan anak jalanan ini perlu di eksplorasi lebih mendalam dan alamiah atau natural untuk mengembangkan Teori yang sudah ada sebelumnya.

Lokasi Penelitian dilakukan di Kota Palangka Raya yang mana sebagai implementator kebijakan dalam hal ini adalah Dinas Sosial Kota Palangka Raya. Dengan pertimbangan kondisi wilayah ini memperlihatkan adanya berbagai masalah dalam penanganan gelandangan, pengemis, tuna susila dan anak jalanan. Sejak dikeluarkannya Perda No. 09 tahun 2012 mengenai Penanganan Gelandangan, pengemis, tuna susila dan anak jalanan kebijakan ini masih belum berjalan maksimal bahkan keberadaan mereka semakin banyak memenuhi kota yang memiliki selogan sebagi 'Kota Cantik'.

Dalam melakukan analisis data Penulis menggunakan analisis data oleh Sugiyono (2015:87). Menurut Sugiyono (2015:87) analisis data adalah proses mencari dan menyusun secara sistematis data yang diperoleh dari hasil wawancara, catatan lapangan, dan dokumentasi, dengan cara mengorganisasikan data ke dalam kategori, menjabarkan ke dalam unit-unit melakukan sintesa menyusun kedalam pola-pola, memilih mana yang penting dan yang akan dipelajari dan membuat kesimpulan sehingga mudah dipahami oleh diri sendiri maupun orang lain. Teknik Analisis yang di gunakan dalam penelitian ini adalah model teknik analisis Interaktif yaitu melalui Reduksi Data, Display Data, dan verifikasi/penarikan kesimpulan.

\section{HASIL PENELITIAN}

\section{Faktor Komunikasi}

Setiap kebijakan akan dapat dilaksanakan dengan baik apabila terjadi komunikasi yang efektif antara pelaksana program (Kebijakan) dengan para kelompok sasaran. Tujuan dan sasaran dari program/kebijakan dapat di sosialisasikan secara baik sehingga dapat menghindari adanya distorsi atas kebijakan dan program. Selama ini pelaksanaan kebijakan penanganan Gelandangan, pengemis, tuna susila dan anak jalanan sudah di jalankan dengan baik oleh Dinas Sosial selaku implementator kebijakan. Penanganan 
berupa Penertiban, Rehabilitasi sementara dan pemulangan ketempat asal.

Secara keseluruhan kebijakan ini memang berjalan baik, namun tetap ada komunikasi yang belum berjalan maksimal sesuai dengan isi Perda Nomor 09 tahun 2012 yang termuat pada pasal 15 menyatakan bahwa yang bertanggung jawab dalam melakukan penanganan utama adalah Dinas Sosial bekerja sama dengan Satuan Polisi Pamong Praja Kota Palangka raya. Satuan Polisi sebagai penegak Perda mempunyai TUPOKSI sebagai penegak Peraturan Daerah seharusnya lebih aktif dalam melakukan penanganan. Selama ini penanganan dilaksanaksanakan 3-4 Kali dalam satu tahun bersama dengan Kepolisian, TNI, Tagana dan BNNK. Selain kurangnya komunikasi para implementaotor, yang menjadi kendala dari implementasi kebijakan penanganan Gelandangan, pengemis, tuna susila dan anak jalanan adalah ketidaktahuan masyarakat akan adanya Kebijakan ini. Sehingga yang harusnya pemerintah dan Masyarakat bisa bersama-sama mengawal kebijakan inipun menjadi terhambat.

\section{Faktor Sumber Daya}

Implementasi kebijakan akan berjalan dengan baik apabila di imbangi dengan sumber daya yang mencukupi. Yang mana tidak dapat di pungkiri bahwa sumber daya menjadi faktor utama berjalan atau tidaknya suatu kebijakan. Menurut Edwar III dalam buku Diyanto Indiahono (2009 : 31-33) menyatakan, Sumber daya, meliputi empat komponen yaitu staf yang cukup (jumlah dan mutu), informasi yang dibutuhkan guna pengambilan keputusan, kewenangan yang cukup guna melaksanakan tugas atau tanggung jawab dan fasilitas yang dibutuhkan dalam pelaksanaan. Dalam pelaksanaan nya selama ini penanganan gelandnagan, pengemis, tuna susila dan anak jalanan di komandoi oleh kepala Kasi Rehabilitasi Sosial dan Tuna Susial sebab untuk Kepala Bidang saat ini tengah Kosong karena Pensiun. Untuk saat ini jumlah staf karyawan dinas sosial sudah mencukupi, hanya sedikit terkendala dengan kurangnya staf yang memiliki disiplin ilmu sosial. Sebab dalam penyelesaian permasalahan sosial yang begitu kompleks dibutuhkan karyawan yang benar-benar bisa memahami psikologi para pelaku sehingga mereka bisa paham dan tidak kembali mengulangi perbuatan mereka.

Sumber daya finansial merupakan tonggak utama yang harus disiapkan sebelum memutuskan suatu kebijakan. Sebab finansial yang kurang berdampak dengan hasil dari kebijakan di lapangan. Perda nomor 09 tahun 2012 sudah berjalan selama 6 tahun lamanya namun keberadaan gelandangan, pengemis, tuna susila dan anak jalanan masih belum menunjukan pengurangan jumlah, sifatnya Pluktuatif bahkan cenderung meningkat. Salah satu yang menajadi kendala belum maksimalnya kebijakan adalah karena masih belum adanya panti rehabilitasi sosial sebagai penampung bagi gelandangan, pengemis, tuna susila dan anak jalanan yang terjaring dari rajia. Selama ini yang ada hanya rumah singgah dengan kapasitas yang tidak terlalu besar. Dengan adanya panti rehabiitasi diharapkan para pelaku penyandang masalah kesejahteraan sosial (PMKS) ini bisa dilatih untuk bisa percaya diri kembali ke masyarakat dengan beberapa keahlian.

\section{Faktor Disposisi}

Disposisi atau sikap dari pelaksana kebijakan adalah faktor penting ketiga dalam pendekatan mengenai pelaksanaan suatu kebijakan publik. Jika pelaksanaan suatu kebijakan ingin efektif, maka para pelaksanan kebijakan tidak hanya harus mengetahui apa yang akan dilakukan tetapi juga harus memiliki kemampuan untuk melaksanakannya, sehingga dalam praktiknya tidak menjadi bias. Karakter yang penting dimiliki oleh implementror adalah kejujuran, komitmen dan demokratis. Implementor yang memiliki komitmen tinggi dan jujur akan senantiasa bertahan di antara hambatan yang ditemui dalam program/kebijakan. Kejujuran mengarahkan implementor untuk tetap berada dalam arah program yang telah digariskan dalam guideline program. 
Para impelementaor kebijakan harus bisa memperhatikan sikapnya dalam bertindak agar masyrakat sebagai pelaksana dari kebijakan tidak menjadi salah fokus dalam menjalanakan kebijakan. Kegagalan dari implementasi kebijakan biasanya sering disebabkan oleh tidak patuhnya staff dalam menjalankan tugas. Oleh karena itu pengangkatan birokrat harus benar-benar di seleksi sesuai dengan kebutuhan. Sebagai penunjang pelaksanaan Dinas Sosial selaku bagian dari pemerintah yang mendapatkan Tugas dan Pungsi (TUPOKSI) cukup besar dalam menangani gelandangan, pengemis, tuna susila dan anak jalanan di kota Palangka Raya sudah melakukan tindakan sesuai dengan amanat kebijakan. Untuk menunjang agar dalam pelaksanaan bisa berjalan maksimal, Pemerintah daerah kedepannya diharapakan agar bisa memberikan insentif tambahan bagi para Pekerja sosial ini. Sebab dalam menyelesaikan permasalahan yang begitu kompleks ini tidak mudah dan harus turun langsung ke masyarakat.

\section{Faktor Sruktur Birokrasi}

Walaupun sumber-daya untuk melaksanakan suatu kebijakan tersedia atau para pelaksana kebijakan mengetahuai apa yang seharusnya dilakukan, dan mempunyai keinginan untuk melaksanakan suatu kebijakan, kemungkinan kebijakan tersebut tidak dapat terlaksana karena terdapat kelemahan dalam struktur birokrasi. Kebijakan yang begitu kompleks menuntut adanya kerjasama banyak orang, ketika struktur birokrasi tidak kondusif pada kebijakan yang tersedia, maka hal ini akan menyebabkan sumber-sumber daya menjadi tidak efektif dan tidak termotivasi sehingga menghambat jalannya kebijakan. Gelandangan, pengemis, tuna susila dan anak jalanan yang berada di kota Palangka Raya merupakan orang-orang yang sudah pernah di tangani oleh pemerintah Daerah namun terus kemabali tanpa jera. Untuk mengatasi itu semua Kepala Dina sosial pun tidak diam dan melakukan Fragmentasi atau menyebar tanggung jawab keberbagai aktivitas, kegiatan atau program pada beberapa unit kerja yang sesuai dengan bidangnya masing-masing.
Dalam fragmentasi tersebut Kepala Dinas Sosial menyatukan beberapa aparat keamanan untuk membantu dalam melakukan penertiban dalam sebuah Surat Keputusn (SK) yang di tanda tanangi langsung oleh kepala dinas dan hasil dari koordinasi dnegan pemerintah daearah. Dengang terfragmentasinya struktur birokrasi, maka implementasi akan lebih efektif karena dilaksanakan oleh oraganisasi yang kompeten dan kredibel.

\section{PEMBAHASAN}

\section{Implementasi Kebijakan Penanganan Gelandangan, Pengemis, Tuna Susila dan Anak Jalanan di Kota Palangka Raya}

Dibuatnya suatu kebijakan pasti memiliki tujuan dan masalah yang harus segera di selesaikan berdasarkan pertimbangan-pertimbangan yang sudah matang sebelumnya. Sesuai dengan apa yang dikemukankan oleh Van Meter dan Van Horn (dalam Budi Winarno 2008:146-147) bahwa implementasi kebijakan merupakan sebagai tindakan-tindakan dalam keputusankeputusan sebelumnya yang dilakukan oleh organisasi publik yang diarahkan untuk mencapai tujuan- tujuan yang telah ditetapkan. Seperti yang sudah di jelaskan penulis sebelumnya bahwa implementasi kebijakan tentang penanganan gelandangan, pengemis, tuna susila dan anak jalanan merupakan pekerjaan yang belum memiliki titik terang untuk terselesaikan. Menurut Edwar III dalam Diyanto Indiahono (2009 : 31-33) mengemukan berhasil tidaknya suatu kebiajakn dapat dilihat menggunakan 4 Indikator yaitu, Komunikasi, Sumber Daya, Disposisi dan Struktur Birokrasi. Selama ini dalam pelaksanaannya Dinas Sosial selaku instansi yang bertanggung jawab sebagai pelaksana kebijakan sudah berusaha sebaik mungkin dalam menjalakan kebijakan. Namun dari semua indikator tersebut ada dua hal yang menjadi kendala yang mebuat kurang maksimalnya pelaksanaan penanganan di lapangan yaitu indikator komunikasi dan sumber daya. yang bertanggung jawab dalam menegakan dan menjalankan kebijakan ini seharunya menjadi tugas bersama antara pemerintah dan masyarakat, namun karena 
kurangnya pengetahuan masayarakat akan adanya kebijakan ini membuat implementasinyapun menjadi terhambat. Kurangnya komunikasi ini dikarenakan kurangnya sumber daya yang dimiliki pemerintah, baik berupa sumber daya manusia, finansial, dan penyaluran informasi dan wewenang yang diberikan.

\section{Faktor Pendukung dan Faktor Penghambat}

Faktor pendukung dan faktor pengahambat dalam hal ini dibagi menjadi dua yaitu internal dan eksternal. Dalam internal yang dapat menjadi faktor pendukung dan juga penghambat implementasi kebijakan penanganan gelendangan, pengemis, tuna susila dan anak jalanan adalah Anggaran. Selama ini dalam penangananya dinas sosial selaku pelaksana, menggunkan anggaran yang telah di tetapkan oleh pemerintah daerah dan juga anggaran dari pemerintah pusat. Namun anggaran ini juga menjadi faktor penghambat, karena anggaran yang ada hanya cukup untuk melakukan rehabilitasi dan pendataan sementara saja. Seharusnya sebelum suatu kejakan dibuat pemerintah harus terlebih dahulu menyiapkan fasilitas pendukungnya. Yang mana dalam hal ini dinas sosial terkendala tidak adanya panti rehabilitasi untuk melakukan penanganan secara intensif. Pemerintah daerah harus segera merencanakan dan menganggarkan fasilitasfasilitas pendukung laiinya agar kebijakan ini bisa berjalan dengan maksimal.

Dari hasil penelitian ditemukan bahwa yang menjadi pihak eksternal adalah Kultural masyarakat, regulasi dan Political Will. Sebagai faktor pendukung, kultural masyarakat indonesia yang begitu kental dengan kelembutan dan tatakrama harus bisa bersama-sama saling merangkul dan menguatkan satu dengan yang lainnya. Salah satu hal yang bisa dilakukan oleh masyarakat misalnya dengan tidak memberikan uang kepada pengemis, ini akan membentuk mereka menjadi pribadi yang manja. Akan lebih baik jika masyarakat bersatu dan mebukakan lapangan pekerjaan bagi mereka semua. Dari hasil penelitian ditemukan bahwa Political Will atau kemauan dari pemerintah dalam menangani gelandangan, pengemis, tuna susila dan anak jalanan ini terlihat sudah cukup maksimal yaitu dengan adanya razia rutin yang dilakukan oleh dinas sosial bekerja sama dengan Kepolisian, TNI, Satpol PP, BNN dan tagana.

Kultural masyarakat, regulasi dan Political Will juga bisa menjadi faktor penghambat. Dari hasil pengamatan dilapangan kondisi masyarakat cenderung melakukan pembiaran terhadap adanya geladangan, pengemis, tuna susila dan anak jalanan di kota Palangka Raya. Dan hanya berpaku pada pemerintah, padahal masyarakat adalah sebagai controlling utama dalam bersama-sama mengawal dan menjalankan kebijakan pemerintah. Regulasi kebijakan Perda Nomor 09 tahun 2012 menurut penulis perlu di kaji ulang karena penanganan terhadap gelandangan, pengemis, anak jalanan tidak bisa sama dengan penanganan wanita tuna susila. Sebab keberadaan wanita tuna susila ini tidak hanya berdampak negatif bagi kehidupan sosial namun juga mengakibatkan munculnya penyakit-penyakit menular disebabkan tidak sehatnya pergaulan mereka.

\section{KESIMPULAN}

Secara keseluruhan Dinas Sosial Kota Palangka Raya sudah melaksanakan TUPOKSI nya dengan baik dalam mengimplentasikan kebijakan penanganan gelandangan, pengemis, tuna susila dan anak jalanan di Kota palangka Raya. Hal ini dilihat berdasarkan Teori yang dikemukan oleh Edward III bahwa suatu implementasi kebijakan akan berjalan baik ataupun terhambat dipengaruhi oleh empat indikator yaitu: Komunikasi, Sumber daya, Disposisi dan Struktur Birokrasi. Namun Kendala utama kurang maksimalnya implementasi kebijakan terhadap gelandangan, Pengemis Tuna susila dan anak jalanan ini dikarenakan masih belum adanya pasilitas panti rehabilitasi untuk memberikan bimbingan sosial, maupun mental bagi para pelaku gelandangan pengemis, tuna susila dan anak jalanan ini. Dan yang paling utama pemberian keterampilan bagi para pelaku agar bisa hidup dengan normal berbaur dengan masyarakat. 
Kedua yakni faktor Internal yang mendukung dan menghambat kebijakan adalah Anngaran. Sedangkan faktor eksternal yang dapat menjadi pendukung dan penghambat kebijakan adalah : Kultural Masyarakat, Political Will dan Regulasi kebijakan.

Saran dari peneliti sebagai berikut yakni: Hendaknya Pemerintah daerah bisa lebih mengkomunikasikan dan bekerja sama dengan masyarakat untuk bisa bersama-sama mengawal dan menjalankan kebijakan. Dan penulis juga mengusulkan Kepada badan eksekutif maupun legislatif untuk bisa mengevaluasi kembali Perda Nomor 09 tahun 2012 ini. Sebab dari hasil penelitian yang sudah dilakukan, penanganan terhadap Wanita Tuna Susila tidak cocok di satukan dengan gelanndangan, pengemis dan anak jalanan. Sebab penanganan terhadap wanita tuna susila memerlukan waktu dan penanganan khusus untuk bisa kembali hidup dengan normal dimasyarakat. 


\section{DAFTAR PUSTAKA}

Haedar Akib. 2010. Implementasi Kebijakan (Apa, Mengapa dan bagaimana). Jurnal Administrasi Publik. Volume 1 No.1

Ibrahim. 2015, Metodologi Penelitian Kualitatif, Bandung : Alfabeta, Cv

Indiahono Dwiyanto. 2009, Kebijakan Publik (Berbasis Dynamic Policy Analisys). Yogyakarta: Penerbit Gava Media

Peraturan Daerah Nomor 09 Tahun 2012 Tentang Penanganan Gelandangan Penegemis Tunasusila Dan Anak Jalanan Di Kota Palangkaraya.

Sri Suwtri (2014). Konsep dasar kebijakan publik. Modul analisis kebijakan publik, Mapu5301/modul (1) 5-9

Sugiyono. 2013, Metode Penelitian Pendidikan Pendekatan Kuantitatif, Kualitatif, dan $R \& D$. Bandung: Alfabeta

Sugiyono. 2015, Metode Penelitian Kuantitatif Kualitatif R\&B. Bandung: Penerbit Alfabeta,Cv

Sabatier, Paul A. \& Daniel A. Mazmanian. 1983. The Implementation of Public Policy: A Framework of Analysis. Policy Studies Journal: 1983 